\title{
Support Group
}

National Cancer Institute

\section{Source}

National Cancer Institute. Support Group. NCI Thesaurus. Code C17120.

A group of people who provide each other moral support, information, and advice on problems relating to a shared characteristic or experience. 